\title{
Solidarity Formations Under Flexibilisation: Workplace Struggles of Precarious Migrants in Thailand
}

\author{
Stephen Campbell, University of Toronto, Canada
}

\begin{abstract}
Recent scholarship on precarious labour has called attention to global transformations in employment regimes, which have given management greater freedom in setting the terms of work. Such 'flexibility' in employment is associated with a decrease in work, wage and livelihood security; more temporary, rather than open-ended, job contracts; a roll-back of employment benefits; heavy restrictions on workers' collective organisation; and a greater reliance on migrant labour. To date, scholars have mostly emphasised the negative impact this transformation has had on workers' solidarity. However, as this article highlights, flexibilisation can also function as an enabler of solidarity. Presenting an ethnographic case study of a workplace struggle at an export processing zone in northwest Thailand, it is argued that where flexible labour regimes incite shared grievances among workers and occlude the representative role of trade unions officials, they have facilitated self-organised struggles among workers based on a clear sense of common cause.
\end{abstract}

\section{KEYWORDS}

flexibilisation, migration, Myanmar, precarious labour, Thailand, workplace struggle

When describing the social dynamics of workers' collective action, Myanmar migrants in Thailand have repeatedly drawn on the metaphor of a straw fire (kauk-yo-mi). The idea is that workplace grievances and discontent are widespread without any collective response. Yet a sudden spark can ignite a blaze of mass mobilisation, with those employed at a given workplace rushing into a movement of collective rebellion. Within this observation is recognition of both challenges and opportunities for workplace struggles under local 'flexible' employment regimes. Of particular significance is the implication that while flexibilisation has constrained certain models of labour organising, it has simultaneously enabled alternative forms of workers' collective action. Understanding this dual character of flexibilisation can aid in theorising the dynamics of solidarity under flexible employment regimes, thereby challenging analyses that see in flexibilisation primarily a process of class fragmentation.

Such analyses have emerged within recent scholarship calling attention to transformations in employment regimes across the globe; transformations which have given 
management greater freedom in setting the terms of work (e.g. Standing 2011). Such 'flexibility' in employment has been associated with a decrease in work, wage and livelihood security; more temporary, rather than open-ended, job contracts; a roll-back of employment benefits; heavy restrictions on workers' collective organisation; and a greater reliance on migrant labour. In studies of Euro-American countries, scholars have usually presented flexible labour as the outcome of a movement away from a high-water mark of the terms of work in industrial production that were negotiated under the FordistKeynesian social compact of the mid-twentieth century (Arnold and Bongiovi 2013, Thornley et al. 2010, Neilson and Rossiter 2008). Writing against this historical backdrop, the tendency has been to link the rise of precarious labour to a process of deindustrialisation connected with neoliberal restructuring and labour market transformation that began at the turn of the 1980s (Standing 2011: 6-7, Choi and Mattoni 2010: 214).

The effects of this transformation, according to Guy Standing (2011: 12), have been class fragmentation, an undermining of workers' solidarity and increased difficulties for affected workers to form collective associations - features he links to an emergent 'precariat' class. Given such challenges, Dae-Oup Chang (2009: 176-177) has argued that there is 'an urgent need for the labour movement to develop a new solidarity strategy against the comprehensive recomposition of global labour and, at the same time, differentiated tools of organising labour according to particular forms of informalisation'.

The challenges that flexibilisation poses to labour organising, however, vary according to particular geographical contexts (Coe and Jordhus-Lier 2010). This fact is relevant when considering possibilities for collective action under contemporary labour regimes in Asia. While many of the same features of flexible labour listed above are found in Asian contexts (Deyo 2012, Arnold and Pickles 2011, Lee 2009), flexibilisation in Asia has often emerged alongside intensified industrialisation, rather than deindustrialisation. Indeed, the flexibility of labour has been a major draw for foreign capital investment into the region's targeted industrial production zones (Chang 2009). Given that most writing on precarious labour has focused on advanced industrialised countries (Arnold and Bongiovi 2013: 303), existing analyses that theorise class fragmentation emerging out of deindustrialisation are not wholly transferable to industrialising Asian contexts.

If flexibilisation challenges earlier models of (trade union) organising, it has also exacerbated labour-management tensions and fuelled worker discontent. And where industrialisation has led to the concentration of factory workers under capitalist labour regimes, the social basis for collective workplace struggle is intensified. Among Myanmar migrants in Thailand, with whom I have been conducting research since 2011, the sense is that collective action (albeit not always successful) persists despite flexibilisation, particularly among factory workers. My intention is not, however, simply to point out this persistence of workplace struggle. Rather, my argument is that, in the context of labourintensive manufacturing, flexibilisation has incited collective action and enabled particular forms of workers' self-organisation firmly based on rank-and-file solidarity. In other words, contemporary transformations in capitalist production shape and make possible certain forms of struggle (Hardt and Negri 2001). By taking such existing workplace struggles as points of departure, and appreciating the forms of self-organisation they represent, 
discussion of new organising strategies adapted to flexible labour regimes can aim at building up these rank-and-file organs of collective action.

As a step in this direction, this article presents an ethnographic case study of a workplace struggle initiated by Myanmar migrants at a garment factory in the border district of Mae Sot, Thailand during 2012. The account is based on my own involvement as a participant observer, as well as on group discussions and informal interviews with the workers involved, as part of broader anthropological fieldwork among Myanmar migrants in Thailand (see Campbell 2012a, 2012b). Throughout the duration of this case I was based out of the office of the Yaung Chi Oo Workers' Association, conducting my own research while volunteering to assist the organisation where possible. I accompanied the workers involved during much of the process, soliciting their views of the events as they took place. I was thus not a neutral observer, but rather openly supportive of the workers whose struggle I describe below. In what follows, before presenting the case itself, I sketch some theoretical considerations for understanding the dynamics of solidarity that emerged over the course of this struggle. I then contextualise the case with an overview of the precarity of migrant life in Mae Sot, present the case study, and conclude with some brief remarks summarising the main thrust of my argument.

\section{The Emergence of Solidarity Under Flexibilisation}

The argument that flexibilisation undermines workers' solidarity (and thus collective action) follows in part from analyses which equate such solidarity with formal trade union membership. To illustrate, I turn to a 2012 publication by the Mae Sot branch of the Thai Labour Law Clinic entitled Workers' Solidarity-building Handbook. The foreword refers to the text as a 'handbook on establishing labour unions' (Labour Law Clinic 2012: 3). The content entails information on the role of trade unions under Thai labour law, an excerpt of domestic law on trade union formation, a sample union registration form and information on an existing Thai textile union. Published in Burmese, the handbook is aimed at the local migrant population.

Insofar as worker solidarity is understood in these terms, the data support a narrative of decline over the period of flexibilisation. Industrialisation in Mae Sot has occurred amidst Thailand's labour market deregulation since the late 1980s. In this context, reliance on unregistered migrant workers and lax enforcement of labour laws as means to attract capital investment have engendered conditions ill-conducive to unionisation. A principle barrier has been Thailand's Labour Relations Act B.E. 2518 (1975), which prohibits nonThai nationals from establishing unions. While the act permits non-nationals to join existing Thai unions, such unions have been in decline since the start of market reforms, with a 7 percent drop in union density during the early 1990s, down to a current rate of less than 4 percent of the country's total workforce (Deyo 2012: 143). This decline has meanwhile occurred alongside a steady increase in the number of manufacturing employees in the country (Deyo 2012: 70 - 73). And among migrants in Mae Sot there has not been a single successful unionisation drive. Dae-Oup Chang (2009: 175) thus writes that migrant workers in Thailand are 'excluded almost completely from solidarity protection'. Similarly, looking at labour regime transformations in Thailand's garment industry following the 
1997 Asian financial crisis, Piya Pangsapa (2007: 163) suggests that capital relocation from relatively unionised areas around Bangkok to non-unionised (and more precarious) factories in the country's outlying provinces means that 'strikes and work stoppages are becoming a thing of the past'.

The narrative is less bleak, however, when solidarity is understood not in terms of formal trade union membership, but more generally as rank-and-file collective action over shared workplace grievances. Labelling this form of organising as 'solidarity unionism', Straughton Lynd and Daniel Gross (2007: 354) define it as follows:

Workers rather than outside organizers reach out to potential new members, worker by worker. [Workers] organize around issues of common concern regardless of whether a majority of workers in a given workplace, or group of workplaces, are union members.

Understanding solidarity thus, flexibilisation has, in fact, facilitated its emergence in Mae Sot. This has occurred in two ways. First, as Frederic Deyo (2012: 131) points out, labour deregulation in East Asia has shifted employment arrangements in light manufacturing away from (using Michael Burawoy's terms) 'hegemonic regimes' towards 'market despotism'. Under the former, employers rely primarily on worker consent and cooperation to ensure production, whereas under the latter employers utilise coercion and 'the economic whip of the market' (Burawoy 1985: 122). The oppressive conditions of despotic regimes tend, however, to heighten labour-management tensions and increase workplace conflict.

The second way in which flexibilisation has enabled solidarity in Mae Sot has been through the promotion - as an industrialisation strategy - of a migrant workforce lacking the protections of formal union membership. Conventional union structures tend to channel workers' concerns into formal collective bargaining processes and bureaucratic grievance procedures that privilege the representative function of trade union officials while reducing direct rank-and-file control over collective action (Glaberman 2002, Brinton 2004). This has in Thailand allowed for close collaborative relations between the leaders of union federations, government agencies and political parties, which have 'blunted and diverted' the responses of unions to market reforms (Deyo 2012: 147). Regardless of the relative success (or not) of particular workplace struggles by migrants in Mae Sot, the nonunionised status of these workers has meant that their collective actions are necessarily selforganised, rank-and-file controlled and dependant on informal labour solidarities.

With these two factors in play, solidarities have repeatedly emerged among workers in Mae Sot's garment industry through a triple movement. First, under regimes of market despotism, low wages and oppressive working conditions have fuelled collective grievances among those employed at a given worksite. Second, the absence of union-managed grievance procedures has led workers to initiate collective action without the mediation of trade union officials. Third, the centripetal force of direct, collective involvement in common struggle has intensified solidarities among participating workers (c.f. Fantasia 1988). These theoretical considerations aid in understanding the repeated emergence of solidarity amongst what is an otherwise highly precarious migrant workforce in Mae Sot. 


\section{The Production of Precarity in Mae Sot}

Situated at the foot of the mountains in northwest Thailand some eight hours by road from Bangkok, the once bucolic outpost of Mae Sot has developed over the past two decades into a thriving industrial zone. Garment and textile factories, corn and sugarcane plantations, a bustling gem market, and a large volume of border trade with Myanmar have fuelled the town's rapid development boom. Industrialisation in Mae Sot has been part of a larger process of economic integration in mainland Southeast Asia since the late 1980s, with regional states seeking an increase in trade, the unhindered flow of capital, and the (controlled) movement of labour across national borders. To these ends, the Thai state has sought to entice capital from abroad by providing investment incentives to foreign firms, such as tax breaks and lax labour protection standards within targeted export processing zones, such as Mae Sot (Arnold and Hewison 2006). By applying geographically-delimited, production-focused governance, Thai authorities have endeavoured to manage migrant flows and maximise employers' flexibility to set the terms of work, thereby fostering the area's precarious labour force (Arnold and Pickels 2011). This creation of a precarious workforce in Mae Sot has thus been described as 'an integral part' of the Thai state's development strategy (Lee and Kofman 2012: 394).

In Mae Sot and its neighbouring districts of Phop Phra, Umphang, Mae Ramat and Tha Song Yang there are an estimated 200,000 plus Myanmar workers employed in garment and textile manufacturing at around 300 largely foreign owned factories, another hundred or so unregistered 'home factories', as well as in the agriculture, construction, and service sectors (Aung and Aung 2009: 25). An estimated 70 percent of these workers are women (Pollock and Aung 2010: 217). Due to its position on the Myanmar border, Mae Sot serves as an entry point for migrants leaving the political and economic difficulties of their home country to seek work in Thailand (International Rescue Committee 2012: 914). There is thus a regular flow of new arrivals with little or no experience of Thailand, no Thai language ability and no documentation for legal residence or work. Many of these individuals quickly find employment at local garment factories, where on-the-job training takes less than a week and living quarters are immediately available on factory premises.

Since the 2009 introduction of 'temporary passports' for migrants many of those formerly based in Mae Sot have left to work in Bangkok or other provinces where wages are higher (Sirima 2012). Although the daily minimum wage for Tak Province, where Mae Sot is located, was raised from 162 baht to 226 baht on 1 April 2012, it remains among the lowest of Thailand's provincially-specific rates. ${ }^{1}$ The minimum wage for Bangkok, by contrast, was raised at the same time to 300 baht. Official rates, however, are deceptive. The overwhelming majority of migrants in the Mae Sot area are paid less than the legal minimum (Waites 2011). Among migrants who have stayed in Mae Sot despite the low wages, many have told me that their reason for doing so is the difficulty they have had saving sufficient funds to pay for the migrant passport. This document (along with visa, work permit, health check, medical insurance and processing charges) costs between 9,500 and 15,000 baht depending on the broker or company processing the application and whether the applicant was previously registered under Thailand's prior work permit scheme. Thus, according to figures given to me by the Mae Sot branch of Thailand's Department of Employment, as of July 2012 the number of migrants holding passports 
and work permits registered in Mae Sot and the four surrounding districts was 10,012; no more than 5 percent of the estimated migrant population.

This lack of documentation acts as a significant constraint on the capacities of migrants in Mae Sot to demand higher wages and better working conditions (Allchin 2011). As numerous migrants have recounted to me, factory managers often threaten to call in the police to arrest insubordinate workers on grounds of their illegal status in the country. ${ }^{2}$ This is despite the fact that it is standard practice at factories in the area to deduct 100 to 150 baht per month from the wages of each undocumented worker in order to pay off the police and prevent a raid. Even without calling in the police, employers often fire those who attempt to organise their co-workers. Employers also fire workers who become pregnant or who miss work due to illness. Given the lack of documentation among the majority of Mae Sot's factory workers, the non-enforcement of Tak's minimum wage, employers' ability to arbitrarily dismiss workers or have them arrested, and the regular arrival of new migrants seeking work, employers in the Mae Sot area are in a strong position to enforce egregiously low wages and poor working conditions. Therefore, aside from payment below the legal minimum, factory workers on a day-rate or piece-rate are occasionally put off work without wages, getting only room and board, when there is a drop in orders or when employers want to cut costs without losing the factory's workforce. In this way employers are able to offload the risks of market fluctuations onto the workers.

In addition to the 100-150 baht taken monthly from the wages of undocumented workers to pay off the police, employers also make deductions for dormitory lodging and provisions rice, electricity, and water. Aside from these upfront deductions, factory workers face additional arbitrary deductions taken on the grounds that they have violated certain factory rules, or for reasons that remain completely opaque. Net wages after deductions are by standard practice not paid until well into the month following the designated pay period, usually on the $10^{\text {th }}$ or $15^{\text {th }}$ calendar day. This arrangement (known by the Burmese term yet-baung-kyay) means that workers who wish to quit on pay day cannot get all the wages owed to them unless they return to collect this money on pay day the following month. Given the difficulty travelling without documentation, the distance between factories and workers' limited free time, many who take on new work elsewhere are unable to return to collect this back-pay. In any case, employers often tell workers who quit that they will not be given the remaining wages owed to them. Within this context of insecurity, migrant workers have suffered violence, and occasionally murder, in connection to disputes with their employers or the Thai police (e.g. Human Rights Watch 2010: 41-45).

Given the poor wages and working conditions, Thai authorities have had to rely on selective movement restrictions in order to build up and maintain Mae Sot's reserve of migrant labour. It is thus extremely easy to cross the Moei River into Mae Sot from Myanmar in broad daylight without legal documentation, but police and military checkpoints on the main roads out of town prevent the free movement of undocumented migrants to higher paying employment elsewhere in Thailand. Following a sharp increase in the number of migrants applying for temporary passports and 'legally' leaving Mae Sot at the start of 2012 - a trend which risked leading to a local labour shortage - the Deputy Governor of Tak Province issued new restrictions in June 2012 at the behest of the Thai Federation of Industries (Tak chapter) barring those holding these passports but not yet 
registered for work outside Mae Sot from freely travelling past the main checkpoint outside town on the road to Bangkok (Weng 2012).

The situation described here is now widely known, and many of these problems have previously been documented by Human Rights Watch (2010) and Amnesty International (2005). Although Thailand's Labour Relations Act prohibits non-Thai nationals from establishing unions to address these issues, it does allow these workers to file cases over labour law violations with the government's Labour Protection Office (LPO), irrespective of their nationality or legal status. After much lobbying and pressure by labour rights organisations (specifically, the Yaung Chi Oo Workers' Association, the Migrant Assistance Programme [MAP] Foundation and the Action Network for Migrants), the Thai government opened a Mae Sot LPO branch in 2004. Despite the barriers to accessing the LPO some migrants have been able to win legal redress for workplace grievances through this channel. Often this has been with legal and logistical resources, and strategic advice from local organisations like Yaung Chi Oo, the MAP Foundation and the Joint Action Committee for Burmese Affairs (JACBA).

Among the implications of the poor conditions for migrant workers in Mae Sot is a significant challenge earning enough money to build savings or send remittances to family back home. Indeed, some migrants find that they end up in a debt trap after arriving at factory gates with little money and in need of work, as interest on goods bought with credit at the factory store is typically 20 percent per month. Those who decide after starting work that the wages and conditions are not worth remaining may find it difficult to quit and seek employment elsewhere or to return home to Myanmar. This is due largely to the fact that they lack sufficient money with which to travel and support themselves while out of work. The difficulty of leaving the factory is increased for undocumented migrants who risk extortion, detention and deportation should they be stopped by the police. Nonetheless, employee turnover is high, with some factories changing 10 percent of their workforce each month, as older workers quit or get fired and new migrants arrive at factory gates.

The precarity of labour in Mae Sot, produced through targeted production-focused governance and the management of migrant flows, serves an important role for local border area industrialisation. In particular, the insecurity of workers has facilitated employers' drives to reduce labour costs, bringing them down to rates significantly lower than elsewhere in Thailand. The low cost (and abundance) of labour in Mae Sot has, in turn, been the major attraction for foreign capital investment into this otherwise obscure location. Yet under these conditions workers have repeatedly organised themselves to address their grievances through workplace struggles despite their non-unionised status. The following case is just one example of such actions.

\section{The Case of M-Apparel Co. Ltd.}

The M-Apparel garment factory, located in a semi-rural neighbourhood outside the town of Mae Sot, began production in September 2010. According to the workers employed there, the factory was at the time of this case owned by a Thai businessman based in Bangkok. As of May 2012 it was employing almost 400 Myanmar workers in its cutting, sewing and packing departments, of whom about 75 percent were women. The workforce 
included ethnic Burmans, Rakhines, Mons and Karens. At this time none of these workers had migrant passports or work permits and only about two thirds had local residence permits, the originals of which the manager withheld. Some had only been in Thailand a month or two. Most of the workers were around 18-20 years old, although I met one 14year-old girl employed there who told me she was not the only one her age. Production workers at this time were being paid a daily wage of 70, 80, 90 or 100 baht depending on their skills and experience. Supervisors were paid 140 to 160 baht per day. Since none had work permits, the wages of all the workers were deducted 150 baht each month to pay off the police. The standard workday went from 8:00 am to 5:00 pm, with overtime starting at 6:00 pm and usually continuing until 11:00 pm. The employer provided dormitory lodging, rice and water, which the workers said were insufficient. The dormitory was so overcrowded that, as one woman complained, 'There isn't even enough room to roll over while you sleep'. As a result, about half the workforce rented rooms outside at an additional cost of 1,000 to 1,500 baht per month. The tenth day of each month was designated payday, with the following day being the sole day off. At the time of the events described below the factory was manufacturing garments for 'Hybrid Threads' and 'Lee School Girls', the latter a product line of the New York-based LT Apparel Group.

I first met workers from M-Apparel on the morning of 15 May when I arrived at the Yaung Chi Oo office and encountered 22 of them sitting on the floor. They were in the process of planning the next steps for the collective action in which they had suddenly found themselves. As they went on to explain, everyone at their factory had walked off the job the previous day. And now, as one of them put it, 'even the cooks are on strike'.

Prior to this eruption of conflict, grievances about the employer had been building. Mostly these concerned wages, work time and the treatment of workers by the manager (an Indian national) and certain Myanmar line supervisors. The workers complained that they were only allowed five minutes to go to the toilet; were given neither Thai nor Myanmar holidays off; were harassed by the supervisors if they took time off for illness; and were forced to work overtime. If they tried to refuse a particular overtime shift, the manager would threaten to deduct 3 or 4 days' wages from their monthly pay. The manager had also told the workers that if they quit on pay day after getting their wages, he would not pay them for the 10 days they had worked in the current month (yet-baung-kyay), and those who quit before pay day would not be paid at all. He had additionally threatened to fire workers who organised a strike, saying that if one occurred, he would call the police to arrest any workers who were involved. Compounding the problem of low pay, the workers were heavily dependent on overpriced goods and curry sold at the factory store, as there were few other shops nearby. As a result, many of these workers were in debt to this store, which sold on credit at 20 percent monthly interest, and few had been able to send remittances to family in Myanmar. Given these conditions there was a regular turnover of 30 to 40 workers each month. Prior to walking off the job on 14 May the workers had frequently complained to each other about the poor wages and work conditions. None, however, had wanted take any collective action because they were worried of being fired or arrested.

While their grievances were many, the catalyst for the 14 May walkout was the employer's repeated delays in paying their wages. When the workers had gone to collect 
their pay on 10 May, the manager had told them that he did not yet have their money; they would have to wait until 14 May. However, when they went back to collect their wages on 14 May after the day shift ended at 5:00 pm, the Thai accountant informed them that the employer again did not have their money and they would have to wait until 17 May. Hearing this, the workers became angry and began voicing their displeasure. Discussions then broke out among the workers gathered in front of the factory office. Some began saying they would not go to work for the $6: 00 \mathrm{pm}$ overtime shift. Soon all the workers were in agreement and none had any intention to work overtime that night. As one worker later described to me, 'The solidarity (nyi-nyunt-yay) among the workers emerged all of a sudden when we were deciding together not go back to work. It wasn't based on any earlier organising'. Another explained, 'There was no leadership when this action started. The workers just decided together'. When the manager realised what was happening he told the workers that those who did not go to work for the 6:00 overtime shift would not be paid at all. This threat was evidently ineffective as no one went to work that night. At that point, none of the workers had a clear plan of what to do next. One individual had a phone number for Yaung Chi Oo and called the organisation, which promised to send a pickup truck the following day to bring some of the workers to the office to discuss the situation.

On the morning of 15 May, the employer offered to pay those workers who returned to work, but said those who did not work would have to leave the factory compound. This appeal, however, was unsuccessful. Those I spoke with later that morning said they did not trust the manager and expected that he would just do the same thing again in the future. As one of them described, 'It's been like this for about two years, with threats and low wages'. Even the proprietor of the factory store had lost confidence in the manager and was no longer allowing purchases on credit as he was uncertain whether the workers would ever be able to repay their debts. Given these conditions, only about 20 people, mostly recent hires and a handful of supervisors, had gone back to work for the morning shift.

As we discussed these events at the Yaung Chi Oo office, a Thai lawyer from the MAP Foundation arrived and explained to the workers their legal right to submit demands through the LPO. However, under Thailand's Labour Relations Act, the LPO will only hear a case if submitted with the signatures of 15 percent of those employed at the affected workplace. Yaung Chi Oo staff had explained some of this the previous day to those who had contacted the organisation. These workers had thus begun collecting signatures on the night of 14 May. At the Yaung Chi Oo office on 15 May, however, their list had only 51 names, just short of the required 15 percent. Those who had come to the office explained that many of their co-workers had been scared to sign the list as they were worried the manager would cause problems for them given they had no passports or work permits. At this time most of the other workers were waiting at a Buddhist forest monastery near the factory. The workers we were speaking with therefore requested that we all go to the monastery, explain the case submission process and encourage the other workers to sign their names.

When we arrived at the monastery we saw about 150 to 200 Myanmar migrants dispersed beneath the trees. JACBA's U Moe Kyo was already there. There were also two plain clothes Thai men whom U Moe Kyo identified as immigration intelligence. They soon left after asking some questions and taking some photos. I approached various workers 
and asked them about the situation. Some admitted they were scared. The workers we had come with then called everyone together. My Yaung Chi Oo colleague explained to them that they needed more signatures if they wanted to submit demands through the LPO. They would also need to select seven temporary representatives for the negotiation process, and should have an eighth to act as liaison when the negotiations were in session. After this explanation the meeting broke up and workers interested in adding their signatures crowded around the list, which soon reached 209 names. Some workers encouraged their friends to volunteer as representatives. Trying to refuse, one such young woman responded, 'I don't know how to talk' (m'pyaw-tet-boo). Nonetheless, her friends got her to accept this role. Soon the workers had selected their eight representatives (four women and four men), none of whom had any experience in workplace organising. Throughout the duration of this case, these eight workers acted as the core of the strike committee, coordinating the legal, logistical and strategic aspects of the action together with a dozen or so other interested workers who were not serving as representatives.

After being selected, the representatives gathered everyone together to hash out their collective demands in a large assembly of workers. The staff from the various organisations provided information on Thai labour law and the workers in the crowd called out their various grievances. The group discussed, debated, amended and accepted or rejected the suggestions that were called out. Eventually, the workers decided on the following demands:

1. Payment of the daily minimum wage of 226 baht

2. Regular wage payments no later than the 5 th day of each month

3. Freedom for workers to change employers, with the manager returning the documentation of those who decide to leave

4. Payment of double wages for work done on the weekly day off

5. An end to intimidation and to dismissals of workers who have committed no work-related errors

6. An end to the supervisors' verbal abuse of workers

The plan was to type up the demands and submit them to the LPO the following day, at which time everyone would return to work in order to avoid dismissal. Accordingly, I went by truck with the Yaung Chi Oo, MAP and JACBA staff to the LPO to inform them about the M-Apparel case. The LPO official scheduled a negotiation session for 17 May and agreed to meet with the manager to tell him to let the workers back into the factory.

At this time most of the workers had not eaten all day. We therefore went and purchased 150 take-out meals of rice and curry from a Myanmar restaurant in Mae Sot and took them back to the monastery. When we arrived there was a meeting going on about the negotiation process, involving the representatives and about two dozen other interested workers. Staff members from Yaung Chi Oo, MAP and JACBA provided legal information, suggestions and encouragement. A colleague from MAP advised, 'Don't think that if you're not a representative, that you don't need to involve yourself in the process. You may have to take on the role of representative at some point'. When the meeting finished, these workers left and joined their friends under the trees. I approached one group and asked 
how they were feeling. Smiling, one woman responded, 'I'm happy. We're going to succeed'.

Two days later (17 May) I cycled over to the LPO and met with the M-Apparel representatives before their negotiation session. They went in at 2:00 pm and came out smiling almost three hours later. They told me the manager had accepted all of their demands except the wage increase. The manager had told them that he would have to confer with the owner about any changes to the wage rate. A second negotiation session concerning this issue was consequently scheduled for 29 May. Nonetheless, the representatives felt the day's negotiations had been successful and they phoned their coworkers at the factory to inform them of the outcome.

In the evening on 23 May, however, I got a call from one of the workers. He told me that the manager had called a meeting with the representatives and they had been inside his office for almost two hours. The individual who called me said that he and his co-workers were concerned about their colleagues in the office, who had not even come out for dinner. As we later found out, the manager was at this time trying to get the representatives to cancel the 29 May LPO negotiation session. Instead, he wanted them to come to an agreement at the factory about the wages. The representatives, however, would not agree to this and remained firm about negotiating at the LPO.

On the morning of 29 May, I met with the M-Apparel representatives at the Yaung Chi Oo office as they prepared for the coming negotiation session. Over the prior week another 99 workers had added their signatures to the list of demands, raising the total to 308. One of the organisers explained that his initially reluctant co-workers had added their names as they learned more about the process and gained confidence in the likelihood of success. As the scheduled meeting time approached we drove to the LPO. The representatives went in while I waited outside with the worker acting as liaison. When the representatives re-emerged shortly before noon they informed me that they had not reached an agreement with the manager. They had repeatedly lowered the amount they were demanding down to a single rate of 160 baht for all the workers. However, the manager was only willing to accept a 50 baht increase to the existing four-level pay structure, raising the wages to $120,130,140$ and 150 baht per day according to workers' skills and experience. The LPO official had suggested a 'compromise' of a four-level pay structure of 120, 130, 140 and 155 baht per day. Neither the workers nor the manager were willing to accept this option.

Due to the deadlock, the LPO official told both parties to return to the workplace, talk with the other workers and try to come up with a solution. She would visit the factory herself at 1:30 pm that day for a meeting with all the workers and the manager. She also told the parties that if they could not reach an agreement by 5 June, then the manager would be obliged to pay the legal minimum wage of 226 baht per day, but would not have to provide room and board for the workers, who would need to support themselves outside the factory with no immigration protection from the employer.

At this point the workers and I climbed into the back of a hired pickup truck, which took us to the factory. Along the way those I was sitting with made repeated phone calls to various co-workers telling them to gather everyone outside for a meeting. After pulling up to the factory gates we climbed out of the truck and joined a mass of workers walking 
towards a nearby cow pasture. It was just past twelve o'clock and these workers were coming off their morning shift. We gathered below a large tree in the open field and waited for everyone to arrive. Soon there were about 200 workers sitting or standing in a large circle, with some holding umbrellas to protect themselves from the sun. One of the representatives who had taken a prominent role in organising explained the developments at the LPO and the manager's offer of an increased four-level pay structure. As he spoke, workers in the crowd shouted out their disdain for the manager's offer. One, for example, called out, 'We can't accept a wage division. We want an equal (dan-doo) pay rate'! Other workers called out questions, opinions and suggestions. After about half an hour the consensus among the crowd was to reject the four-level pay structure and to maintain the demand of a 160 baht day rate for all workers. The workers' assembly then broke up and people went off to have a bite to eat before the 1:30 meeting with the LPO official inside the factory.

When the workers exited the factory following the afternoon negotiation session, they informed me that no agreement had been reached. Both sides had remained firm with their earlier positions. The LPO official had therefore informed the workers that they could initiate a legal, seven-day strike starting the following day (30 May). If no agreement was reached by 5 June, the employer would have to pay the workers the legal minimum of 226 baht per day, but the workers would have to live outside the factory. Those workers who had been living in the factory dormitory would be allowed to stay there during the strike, but the manager informed them that no rice would be provided and the factory shop that sold curry would be closed. In addition, the factory doors would only be opened to allow dormitory residents in and out from 8:00 to 9:00 am, 12:00 to 1:00 pm and 5:00 to 6:00 pm.

The workers I was speaking with at this time seemed somewhat uncertain about what would happen next. To assure his colleagues one worker declared, 'I'm not scared'. Another explained to me that the workers had become increasingly vocal about their grievances: 'Previously, the workers were afraid to speak up, but now they've burst open (pauk-khwe-bee) and everything is coming out'. These workers then told me that the manager's offer of a four-level pay rate would, if accepted, hurt their solidarity, as those who got the higher rates would be less likely to join collective action in the future. Furthermore, since the assignment of pay level would be at the manager's discretion, most workers, they believed, would get the lowest rate. The manager would also punish insubordinate workers with the lower rates while rewarding obedient workers with the higher rates. Another worker argued that, despite differences in skills and experience, all the workers should get the same pay rate because they were all equally exhausted from the work.

Around 3:30 pm we went back to the field for another meeting of workers to go over the current situation. The representatives summarised the developments and various workers in the crowd called out questions and concerns, to which the representatives or other workers responded. Those in the crowd yelled out their acceptance or rejection of various suggestions put forward. There was, for example, an extended discussion of how to manage food and water arrangements over the coming days. A plan was agreed to whereby 
rice and curry would be cooked at the nearby monastery. The assembly then broke up and the workers dispersed.

Throughout the week-long strike I visited the workers at the monastery almost every day. When I arrived the first day, they were cooking roselle leaves and morning glory, which they had picked wild at a field nearby. They had also organised cooking crews to handle the massive food requirements. Most of the workers, however, had little spare cash with which to buy supplies. Local organisations like Yaung Chi Oo donated sacks of rice and some sympathetic foreigners contributed money or food. Even the Myanmar monk who resided at the monastery went to the market one day and bought bulk supplies of instant noodles and canned fish for the workers.

There was no picket line set up or visible demonstration made in front of the factory. In any case, given the semi-rural location there would have been little public visibility for such actions. However, local Thai and Myanmar journalists did show up to film and interview the workers. There were usually at least a hundred or so workers at the monastery keeping busy with cooking, cleaning, eating or just sitting around chatting. The largest group was always around the outdoor cooking and eating area. The atmosphere was positive with lots of jokes and laughter.

On the first official day of the strike (30 May), some workers informed me that the manager had offered to pay 150 baht per day to anyone who returned to work. Thirty-two workers who were described to me as 'his [the manager's] people' immediately took this offer. These individuals included six of the eleven line supervisors from the sewing department and many of the most recently hired production workers. Everyone else said they would not break the strike.

The final LPO negotiating session took place in the afternoon on 5 June. While the representatives were at the LPO, most of the other workers were waiting back at the monastery. As we waited for the meeting outside the LPO building, one of the representatives who had taken a leading role in organising efforts told me he felt worn out from his duties. Nonetheless, when he and the other representatives came out of the meeting an hour later they were ecstatic. One of the women exclaimed: 'We got 226 baht'! This rate, however, would only apply to the 323 workers who had in the end signed up to the demands. These individuals would all have to live outside the factory compound, but those currently in the dormitory could stay there until 10 June. They told me that getting 226 baht and having to live outside the factory was better than getting their earlier demand of 160 baht and living in the factory dorm.

When we returned by truck to the monastery the representatives called a meeting with about 150 to 200 workers and outlined the conditions of the new contract. As 10 June was to be pay day, and 11 June the day off, all the workers would have to go back to work by 12 June at the latest. The most pressing issue was to find accommodations for the 157 dormitory residents who would now have to live outside. There were also discussions of how to arrange cooking and eating for those still living in the dormitory over the next few days, and what date to return to work. Those in the crowd shouted out various possibilities. The workers then voted with a show of hands and reached a decision to collectively return to work on 10 June. 
The assembly then broke up and the workers left, chatting cheerfully with each other as they went. With the signing of the contract that day, M-Apparel became the first factory in Mae Sot to pay the new legal minimum wage without deductions (MAP Foundation 2012). I asked various workers following the final assembly how they felt about the action. Many of them, but especially those who had been most active in organising, told me they now had more knowledge and confidence with which to take collective action when the opportunity to do so arose again.

Looking back on this case, there are several factors that contributed to the relatively positive outcome. First, like most factories in Mae Sot the workers were housed in a single large dormitory, as well as in cramped row housing just outside the factory. While the dormitory served in part to control the workers, it also provided - along with the external worker housing - an initial forum to discuss grievances, develop friendships and build what Stan Weir (2004: 28) called 'informal work groups' as a basis for solidarity before the collective action took place. Second, the workers were able to get in touch with organisations that could inform them of their legal rights in Thailand and the process for submitting claims through the LPO. Third, the workers were demanding no more than what was legally due. As a consequence, the LPO was obliged to rule in their favour. This would not have been the case had the workers been demanding a wage higher than the legal minimum. It is noteworthy, however, that LPO officials have in previous cases endorsed contracts that fail to meet the minimum wage requirement; the shortfall being reconciled as the cost deducted for room and board in the factory dormitory (e.g. Campbell 2012a). Fourth, the sudden collective eruption of discontent facilitated the quick collection of signatures and submission of the workers' demands to the LPO. In previous cases that I have encountered in Mae Sot individual organisers have been fired before they were able to collect sufficient signatures needed for the LPO case submission.

While the workers in this case mobilised outside the framework of formal unions, Yaung Chi Oo and the other organisations involved nonetheless encouraged them to pursue their concerns through existing legal channels; specifically, the LPO and a legal strike. This may have been strategically wise given the insecurity of migrants in Mae Sot. However, insofar as workers' power to collectively advance their interests lies in their capacity to disrupt production, such legal channels may also constrain workers' potential (by, for example, restricting strikes to seven days following failed LPO negotiations).

\section{Conclusion}

The case presented here of the M-Apparel factory workers is just one example of the many collective initiatives migrant workers in Mae Sot have taken to assert control over their wages and working conditions. The persistence of these actions, if not always successful, challenges analyses that equate workers' solidarity with formal union membership. The current state of labour solidarity can thus not be read off declining statistics of union density. Even further, it has been the very conditions of flexible labour in Mae Sot that have enabled the emergence of these particular forms of workers' selforganisation. 
In industrialising labour contexts like Mae Sot where formal union organising remains heavily restricted, these forms of self-organisation among precarious workers suggest a way forward. Not only have they achieved tangible, if limited, material benefits for the workers involved, but when sufficiently extensive such autonomous industrial actions become an important 'politics of social disorder' with the potential to achieve broader political gains beyond the immediate grievances articulated by workers in a given struggle (Deyo 2012: 240-241, c.f. Cleaver 2000: 44-45). By taking such existing workplace struggles as points of departure (rather than laws on union formation) discussion of new organising strategies adapted to flexible labour regimes can focus on building up these rank-and-file organs of collective action. The remaining challenge, therefore, is how the organs of collective action that emerge among precarious workers in the course of struggle (informal work groups, strike committees, workers' assemblies, etc.) might be strengthened, sustained and connected.

\section{NOTES}

1. The exchange rate at the time of these cases (May - June 2012) was approximately US\$ $1=32$ Thai baht. The official daily minimum wage for Tak Province was later raised to 300 baht on 1 January 2013.

2. The situation summarised in the following paragraphs is gleaned from my fieldwork over 2011-2012, particularly from interviews and informal discussions with migrants who have approached the Yaung Chi Oo Workers' Association for assistance with labour-related cases.

\section{REFERENCES}

Allchin, J. (2011) 'Migrants to Face Challenges in Seeking Minimum Wage', Democratic Voice of Burma, 12 July 2011. Available at: www.dvb.no/news/migrants-to-facechallenges-in-seeking-minimum-wage/16521 [1 October 2012].

Amnesty International (2005) Thailand: The Plight of Burmese Migrant Workers. London: Amnesty International.

Arnold, D. and Bongiovi, J. (2013) 'Precarious, Informalizing and Flexible Work: Transforming Concepts and Understandings', American Behavioral Scientist 57(3): 289308. 
Arnold, D. and Pickles, J. (2011) 'Global Work, Surplus Labor, and the Precarious Economies of the Border', Antipode 43(5): 1598-1624.

Arnold, D. and Hewison, K. (2006) 'Exploitation in Global Supply Chains: Burmese Migrant Workers in Mae Sot, Thailand', Journal of Contemporary Asia 35(3): 319-340.

Aung, K. and Aung, S.L. (2009) Critical Times: Migrants and the Economy in Chiang Mai and Mae Sot. Chiang Mai: MAP Foundation.

Brinton, M. (2004) For Workers' Power: The Selected Writings of Maurice Brinton. Oakland: AK Press.

Burawoy, M. (1985) The Politics of Production: Factory Regimes Under Capitalism and Socialism. London: Verso.

Campbell, S. (2012a) 'Anatomy of a Burmese Workers' Strike in Thailand', Mizzima News, 13 May 2012. Available at: www.mizzima.com/edop/commentary/7104-anatomy-of-aburmese-workers-strike-in-thailand.html [Accessed 1 October 2012].

Campbell, S. (2012b) 'Cross-ethnic Labour Solidarities Among Myanmar Migrants in Thailand', Sojourn: Journal of Social Issues in Southeast Asia 27(2): 260-284.

Chang, D. (2009) 'Informalising Labour in Asia's Global Factory', Journal of Contemporary Asia 39(2): 161-179.

Choi H. and A. Mattoni (2010) 'The Contentious Field of Precarious Work in Italy: Political Actors, Strategies and Coalitions', WorkingUSA: The Journal of Labor and Society 13(2): 213-243.

Cleaver, H. (2000) Reading Capital Politically. Oakland: AK Press.

Coe, N. and Jordhus-Lier, D. (2010) 'Constrained Agency: Re-evaluating the Geographies of Labour', Progress in Human Geography 35(2): 211 - 233.

Deyo, F. (2012) Reforming Asian Labor Systems: Economic Tensions and Worker Dissent. Ithaca: Cornell University Press

Fantasia, R. (1988) Cultures of Solidarity: Consciousness, Action, and Contemporary American Workers. Berkeley: University of California Press.

Glaberman, M. (2002) 'Punching Out', in Lynd, S. (ed) Punching Out and Other Writings (pp. 2-23). Chicago: Charles H. Kerr.

Hardt, M and Negri, A. (2001) Empire. Cambridge, MA: Harvard University Press. 
Human Rights Watch (2010) From the Tiger to the Crocodile: Abuse of Migrants in Thailand. New York: Human Rights Watch.

International Rescue Committee (2012) Surviving or Thriving on the Thai-Burma Border: Vulnerability and Resilience in Mae Sot, Thailand. Bangkok: International Rescue Committee.

Labour Law Clinic (2012) Worker Solidarity Building Handbook [alot-thama si-lon-nyinyunt-yay ti-sauk-chin let-swe-sa-saung]. Mae Sot: Labour Law Clinic.

Lee, C. (2009) Against the Law: Labor Protests in China's Rustbelt and Sunbelt. Berkeley: University of California Press.

Lee, C. and Kofman, Y. (2012) 'The Politics of Precarity: Views beyond the United States,' Work and Occupation 39(4): 388 - 408.

Lynd, S. and Gross, D. (2007) 'Solidarity Unionism at Starbucks: The IWW Uses Section 7', WorkingUSA: The Journal of Labor and Society 10: 347-356.

MAP Foundation (2012) 'Congratulation to 323 Burmese Workers Who Were Victorious in Their Struggle for Wages in Accordance to Thailand's Minimum Wage Law', 19 June 2012. Available at: www.mapfoundationcm.org [Accessed 3 October 2012].

Neilson B. and Rossiter, N. (2008) 'Precarity as a Political Concept, or Fordism as Exception', Theory, Culture and Society 25(7-8): $51-72$.

Pangsapa, P. (2007) Textures of Struggle: The Emergence of Resistance Among Garment Workers in Thailand. Ithica: Cornell University Press.

Pollock, J. and Aung, S.L. (2010) 'Critical Times: Gendering Implications of the Economic Crisis for Migrant Workers From Burma/Myanmar in Thailand', Gender and Development 18(2): 213 - 227.

Sirima, S. (2012) 'Businesses Opting for Migrant Workers to Keep Their Costs Low', The Nation, 8 May 2012. Available at: www.nationmultimedia.com/national/Businessesopting-for=migrant-workers-to-keep-thei-30181469.html [Accessed on 1 October 2012].

Standing, G. (2011) The Precariat: The New Dangerous Class. New York: Bloomsbury Academic.

Thornley, C., Jefferys, S. and Appay, B. (2010) 'Introduction: Globalization and Precarious Forms of Production and Employment: Challenges for Workers and Unions', in C. 
Thornley, S. Jefferys and B. Appay (eds) Globalization and Precarious Forms of Production and Employment (pp. 1-9). Cheltenham: Edward Elgar Publishing Limited.

Waites, D. 'Minimum Wage and the Migrant "Bogeyman”, Democratic Voice of Burma, 25 August 2012. Available at: www.dvb.no/analysis/minimum-wage-and-the-migrantbogeyman/17250 [Accessed 1 October 2012].

Weir, S. (2004) Singlejack Solidarity. Minneapolis: University of Minnesota Press.

Weng, L. (2012) 'Rights Groups Say Migrants Blocked From Leaving Mae Sot', The Irrawaddy, 28 June. Available at: www.irrawaddy.org/archives/15590 [Accessed 3 October 2012].

\section{BIOGRAPHICAL NOTE}

STEPHEN CAMPBELL is a doctoral student in the Department of Anthropology, University of Toronto. [email: stephen.campbell@utoronto.ca] 